applied to sediments of lakes El'gygytgyn, Siberia, Ohrid, Albania/Macedonia and Pingualuit, Canada (Vogel et al., 2008; Rosén et al., 2009). As shown in Figure 2 , FTIRS-inferred TOC, TN and BSi are plotted against values using conventional techniques and the results show a close agreement (Vogel et al., 2008). Although the results look promising, we should keep in mind that this quantitative approach has only been tested on a few lakes and we therefore recommend that some FTIRSinferred values are cross-checked against "conventionally" measured values. With respect to the Lake El'gygytgyn sediment record, FTIRS-inferred BSi concentrations have become one of the most important proxy indicators for assessing past climatic and environmental change at fairly highresolution back to $340 \mathrm{ka}$. In addition to quantitative assessment of biogeochemical properties, FTIRS has also been used to assess past changes in tree line and to infer lake water TOC (Rosén and Persson, 2006). After samples have been freezedried, ground and mixed with potassium bromide, up to 300 samples per day can be analyzed using FTIRS, which is about ten times faster compared to leaching methods (e.g., Müller and Schneider, 1993) commonly used for the determination of BSi concentrations, clearly demonstrating the advantages of FTIRS over conventional methods.

\section{Other research areas and future applications}

FTIRS is widely used in both research and industry as a reliable technique for the measurement and quality control of food and pharmaceuticals. The technique is also used in soil science to complete studies on molecular-level processes at mineral, organic, and bacterial surfaces that influence the biogeochemical cycles of elements (Schnürer et al., 2006). In recent years, the development of the FTIRS microscopy technique makes it also possible to assess specific spectra of components identified with the help of a microscope. One such example is demonstrated in Rosén et al. (2009) where spectra from single diatom valves were assessed. Thanks to the continuous technological development and improvement of FTIR spectroscopy, potential applications of the technique also continue to increase. Considering the variety of applications presented in this newsletter, we encourage more researchers to further develop this method for potential application in marine/ocean or lake sediment science.

\section{References}

Mecozzi, M. and Pietrantonio, E., 2006: Carbohydrates proteins and lipids in fulvic and humic acids of sediments and its relationships with mucilaginous aggregates in the Italian seas, Marine Chemistry, 101: 27-39.

Rosén, P. and Persson, P., 2006: Fourier-transform infrared spectroscopy (FTIRS), a new method to infer past changes in tree-line position and TOC using lake sediment, Journal of Paleolimnology, 35 : 913-923

Rosén, P., Vogel, H., Cunningham, L., Reuss, N., Conley, D. and Persson, P., 2009: Fourier transform infrared spectroscopy, a new method for rapid determination of total organic and inorganic carbon and opal concentration in lake sediments, Journal of Paleolimnology, DOl: 10.1007/s10933-009-9329-4.

Stehfest, K., Toepel, J. and Wilhelm, C., 2005: The application of microFTIR spectroscopy to analyze nutrient stress-related changes in biomass composition of phytoplankton algae, Plant Physiology and Biochemistry, 43: 717-726.

Vogel, H., Rosén, P., Wagner, B., Melles, M. and Persson, P., 2008: Fourier transform infrared spectroscopy, a new cost-effective tool for quantitative analysis of biogeochemical properties in long sediment records, Journal of Paleolimnology, 40: 689-702.

For full references please consult:

www.pages-igbp.org/products/newsletters/ref2009_3.html

\title{
Stable isotopes in chitinous fossils of aquatic invertebrates
}

\author{
Oliver Heiri', M.J. Wooller ${ }^{2}$, M. van Hardenbroek ${ }^{1}$ and Y.V. WANG ${ }^{2,3}$ \\ 'Laboratory of Palaeobotany and Palynology, Utrecht University, The Netherlands; O.M.Heiri@uu.nl \\ ${ }^{2}$ Alaska Stable Isotope Facility, University of Alaska Fairbanks, USA; ${ }^{3}$ Current address: Institute of Geosciences, University of Kiel, Germany

\section{Current stable isotope techniques permit the development of new approaches for reconstructing past climate and aquatic food webs based on chitinous invertebrate fossils from lake sediments.}

Chitin is one of the most abundant macromolecules in the biosphere. It can be found in the cuticles of most invertebrates (Cauchie, 2002) and especially in exoskeletons of insects and crustaceans, where elastic chitin rods are typically embedded in and cross-linked with a matrix of proteins (Nation, 2002; Raabe et al., 2005). Organic invertebrate remains, such as exoskeleton plates, mouthparts, or sclerotized resting stages, preserve well in lake sediments (Fig. 1). After the initial decomposition of degradable material, these structures can remain chemically stable for tens of thousands of years (Stankiewicz et al., 1997a) and, in exceptional cases, chitin may even preserve for millions of years in sediments (Stankiewicz et al., 1997b).

Stable isotope analysis of organic material produced in lakes and their surroundings provides information on past climate and ecosystem processes within lakes (e.g., Meyers and Lallier-Vergès,
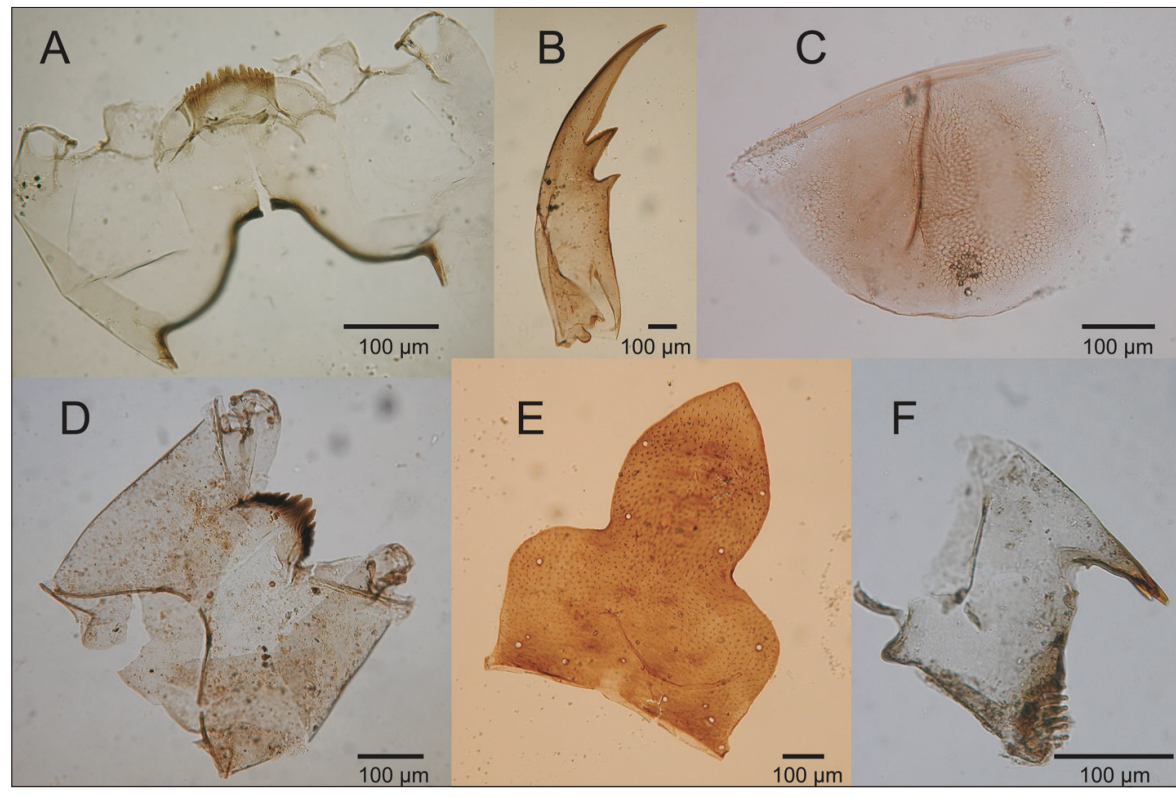

Figure 1: Examples of chitinous fossils produced in lakes and preserved in lake sediments: Head capsules of chironomid larvae (A, Polypedilum nubeculosum-type; $\boldsymbol{D}$, Cricotopus), mandibles of larvae of other aquatic insects ( $\boldsymbol{B}$, Megaloptera; $\boldsymbol{F}$, Ephemeroptera), a resting egg (ephippium) of a water flea (C, Cladocera), and a head capsule part (clypeus) of a caddisfly larva (E, Trichoptera). 


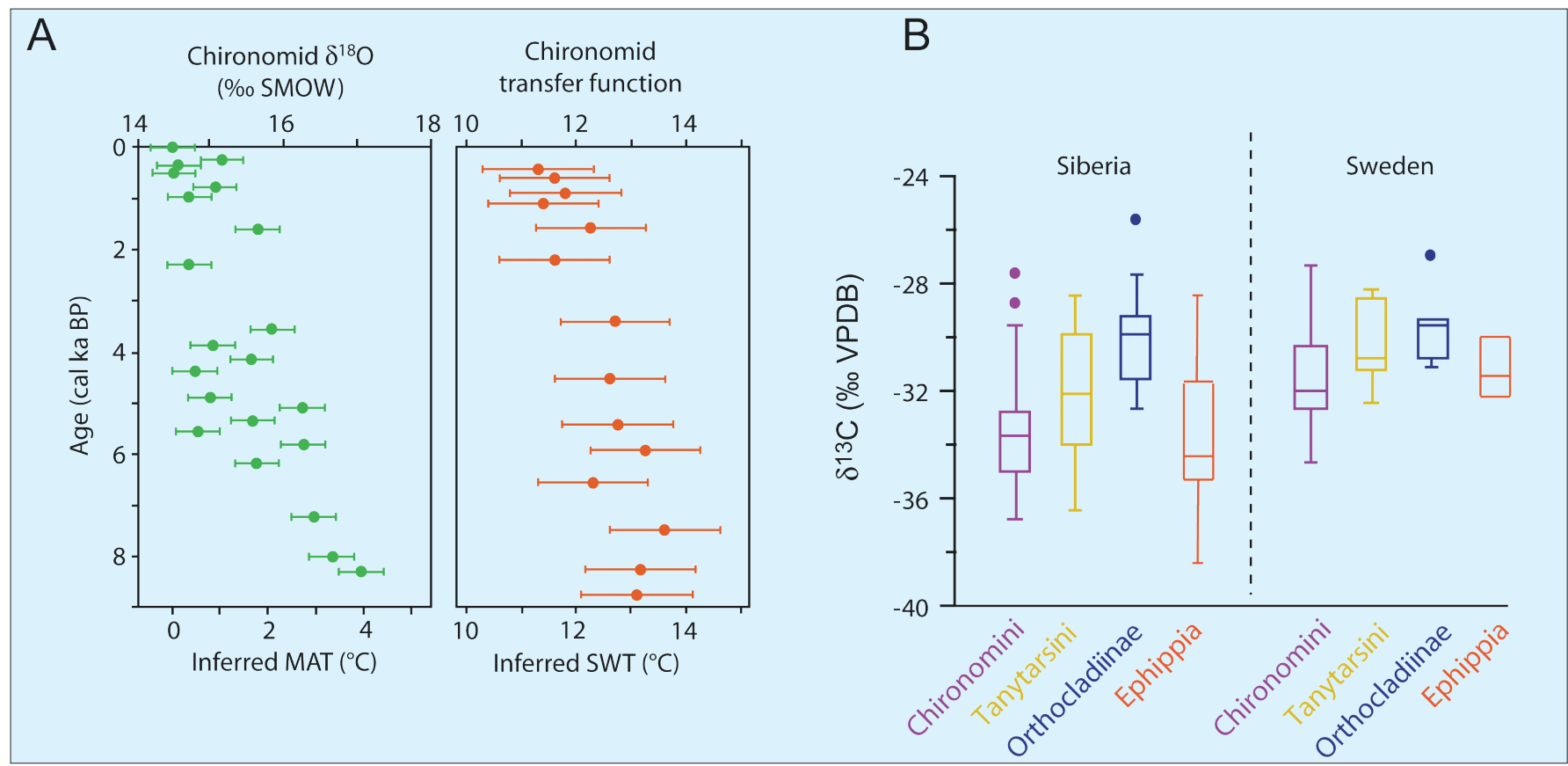

Figure 2: A) Mean annual temperatures (MAT) reconstructed from $\delta^{18} \mathrm{O}$ of fossil chironomids in a Holocene sediment sequence from Qipisarao, Greenland, compared with lake surface water temperature (SWT) inferred from the taxonomic composition of the chironomid assemblages (redrawn from Wooller et al., 2004). B) Taxon-specific $\delta^{13}$ C in subfossil remains of different chironomid groups (Chironomini, Tanytarsini, Orthocladiinae) and of cladoceran resting eggs (ephippia) collected from the surface sediments of lakes in northern Siberia and Sweden (van Hardenbroek. Heiri, unpublished data). Differences in $\delta^{13} \mathrm{C}$ are related to the food ingested by these invertebrates with, e.g., algae typically characterized by $\delta^{13} \mathrm{C}$ of $\sim-25$ to - 30\% (Meyers and Lallier-Vergès, 1999) and methane, which can enter food webs when taken up by methanotrophic bacteria, by values as low as -50 to -80\% (Jones and Grey, 2004). The box plots indicate the 25-75 percent quartiles (box), the median (central horizontal line), and the most extreme values less than 1.5 times the box height from the box (outer horizontal lines). Circles indicate extreme values beyond this range.

1999; Huang et al., 2004; Wolfe et al., 2007). Organic fossils originating from invertebrates contain elements commonly analyzed in stable isotope studies, such as hydrogen, carbon, nitrogen, and oxygen (Schimmelmann, accepted). The potential of stable isotope analysis of invertebrate fossils for paleoecological reconstruction was pointed out more than 20 years ago (Schimmelmann et al., 1986; Miller, 1991). However, to date only a few attempts have been made to analyze stable isotopes in chitinous remains preserved in lake sediments. Advances in stable isotope techniques and instrumentation have significantly decreased the sample mass required for an analysis (Wang et al., 2008; van Hardenbroek et al., 2009a; 2009b). Subsequently, fossils originating from different taxonomic groups (e.g., species, genera, subfamilies) of aquatic invertebrates can be analyzed separately (e.g., van Hardenbroek et al., 2009a). This opens up a range of potential applications in paleolimnological research, which is only expected to expand in the future.

\section{Reconstruction of past climate}

The stable oxygen and hydrogen isotope composition $\left(\delta^{18} \mathrm{O}\right.$ and $\left.\delta^{2} \mathrm{H}\right)$ of precipitation is strongly influenced by temperature and moisture sources. Thus, records of $\delta^{18} \mathrm{O}$ and $\delta^{2} \mathrm{H}$, based on material produced within lakes, can provide insights into past climate as long as the isotopic composition of the analyzed sediment component reflects the former isotopic signature of the water in which it was formed. Carbonate preserved in lake sediments has been widely used to produce $\delta^{18} \mathrm{O}$ records of past climatic changes, reconstructing, for example, major temperature variations in Europe during the Late-Glacial period (e.g., Lotter et al., 1992; von Grafenstein et al., 1999). However, sedimentary carbonates are poorly preserved or absent in many lakes. In contrast, organic invertebrate remains are abundant in the sediments of most lakes and provide an alternative for $\delta^{18} \mathrm{O}$ or $\delta^{2} \mathrm{H}$ analyses. It has been shown that $\delta^{18} \mathrm{O}$ of subfossil head capsules of chironomid larvae reflects the oxygen isotope composition of the water in which they lived (Wooller et al., 2004). Hence, $\delta^{18} \mathrm{O}$ of fossil chironomids can be used to infer the past isotopic composition of lake water and precipitation and, indirectly, to reconstruct past temperature change (Fig. $2 A)$. The distribution of individual chironomid species, species groups, and genera is strongly related to summer temperature. Consequently, chironomid records can also be used to develop paleotemperature estimates using numerical chironomid-temperature transfer functions (e.g., Brooks, 2006). It is therefore possible to produce multiple, independent paleoenvironmental records based on the same proxy indicator: One record based on the taxonomic composition of fossil chironomid assemblages, reflecting past summer temperatures, and another on the strong relationship between the $\delta^{18} \mathrm{O}$ composition of fossil chironomids and mean an- nual temperature (Fig. 2A) (Wooller et al., 2004).

\section{Reconstruction of past aquatic food web processes}

Stable isotope analyses are widely used in food-web studies of contemporary lakes (e.g., Grey, 2006). The $\delta^{13} \mathrm{C}$ and $\delta^{15} \mathrm{~N}$ values of aquatic invertebrates represent the isotopic composition of their food, modified by trophic level and tissue-specific fractionation factors (e.g., Martínez del Rio et al., 2009). Similarly, $\delta^{2} \mathrm{H}$ of aquatic insects also seems to reflect the isotope composition of their diet (Wang et al., 2009). Chitinous fossils of aquatic invertebrates contain carbon, nitrogen, and hydrogen, allowing measurements of $\delta^{13} \mathrm{C}, \delta^{15} \mathrm{~N}$ and $\delta^{2} \mathrm{H}$, and can be used to reconstruct past feeding ecology. For example, it has been demonstrated that $\delta^{13} \mathrm{C}$ can be reliably measured on fossil head capsules of chironomid larvae (e.g., Wooller et al., 2008) and that these measurements reflect $\delta^{13} \mathrm{C}$ in the food available for larval growth (van Hardenbroek et al., 2009a). In lakes, chironomid larvae show a wide range of $\delta^{13} \mathrm{C}$ values depending on whether they feed predominantly on organic matter generated in the photic (photosynthetically active) zone of lakes, or whether the larvae ingest and incorporate methanederived carbon (i.e., from methanotrophic microorganisms) (Jones et al., 2008). Results indicate that $\delta^{13} \mathrm{C}$ differs between chironomid fossils originating from different taxa present in Swedish and Siberian 
lakes (Fig. 2B). Fossils of Chironomini, a group with many species whose larvae live in and burrow into the sediments, tend to have lower $\delta^{13} \mathrm{C}$ than other groups (e.g., Tanytarsini, Orthocladiinae), suggesting that methanotrophic bacteria play a more important role in their diet than in the diets of other chironomids. This finding, together with the observed low $\delta^{13} \mathrm{C}$ in tissue and fossils of other aquatic invertebrates, such as cladocerans (water fleas) (Kankaala et al., 2006; Fig. 2B), suggests that carbon derived from methanotrophic bacteria can be consumed by a range of invertebrate groups where methanotrophic bacteria are an available food source in lakes. Hence, $\delta^{13} \mathrm{C}$ of fossil aquatic invertebrates can provide insights into the past availability and importance of methanotrophic microorganisms in different parts of lake ecosystems and, indirectly, on past methane production and oxidation in lakes (van Hardenbroek et al., 2009a). Similarly, analyses of aquatic invertebrate $\delta^{15} \mathrm{~N}$, and especially the comparison of $\delta^{13} \mathrm{C}$ and $\delta^{15} \mathrm{~N}$, can provide valuable information on changes in the past trophic position of invertebrate groups within lacustrine food webs.

\section{Future directions}

Analytical methods available for analyzing stable isotopes in organic remains of aquatic invertebrates have progressed to the stage where fossils of individual taxa (e.g., species, genera, or subfamilies) can be measured. This allows inferences to be made in respect to past environmental conditions in different parts of lake ecosystems and about past food sources and the past trophic position of aquatic invertebrate taxa. However, the structural integrity of organic microfossils does not guarantee that the chemical composition of these structures has not been altered by degradational or diagenetic processes. Efforts are necessary to assess how degradation potentially affects the stable isotopic composition of these fossils. Moreover, fractionation processes associated with intake of diet and water by aquatic invertebrates need further detailed investigations. In particular, the complex biochemical reactions associated with the formation of the invertebrate exoskeleton could influence the stable isotopic composition of fossilizing structures. Laboratory experiments studying stable isotopes in aquatic invertebrates and their fossilizing structures in respect to the isotopic composition of their food (e.g., van Hardenbroek et al., 2009a) and of lake water (e.g., Wang et al., 2009) are therefore needed to better constrain the interpretation of these stable isotope records from sediments. To develop this approach further, datasets that document the stable isotope composition of aquatic invertebrates in lakes, covering a wide range of environmental conditions, will be necessary. It can be expected that such detailed calibration datasets will allow quantitative paleoenvironmental reconstructions based on stable isotopes of fossil invertebrate remains, and significantly expand both the applicability and reliability of this new approach.

\section{References}

van Hardenbroek, M., Heiri, 0., Grey, J., Bodelier, P.L.E., Verbruggen, F. and Lotter, A.F., 2009a: Fossil chironomid $\delta^{13} \mathrm{C}$ as a proxy for past methanogenic contribution to benthic food webs in lakes? Journal of Paleolimnology, D0I 10.1007/s10933-009-9328-5.

Wang, Y., Francis, D.R., O'Brien, D.M. and Wooller, M.J., 2008: A protocol for preparing subfossil chironomid head capsules (Diptera: (hironomidae) for stable isotope analysis in paleoclimate reconstruction and considerations of contamination sources, Journal of Paleolimnology, 40: 771-781.

Wang, Y.V., O'Brien, D.M., Jenson, J., Francis, D. and Wooller, M.J., 2009 The influence of diet and water on the stable oxygen and hydrogen isotope composition of Chironomidae (Diptera) with paleoecological implications, Oecologia, DOI 10.1007/s00442009-1303-3.

Wooller, M., Wang, Y. and Axford, Y., 2008: A multiple stable isotope record of Late Quaternary limnological changes and chironomid paleoecology from northeastern Iceland, Journal of Paleolimnology, 40: 63-77.

Wooller, M.J., Francis, D., Fogel, M.L., Miller, U., Walker, I.R. and Wolfe, A.P. 2004: Quantitative paleotemperature estimates from $\delta^{18} 0$ of chironomid head capsules preserved in arctic lake sediments, Journal of Paleolimnology, 31: 267-274.

For full references please consult:

www.pages-igbp.org/products/newsletters/ref2009_3.html

\title{
Microbial membrane lipids in lake sediments as a paleothermometer
}

\author{
Johan W.H. Weijers ${ }^{1}$, C.I. Blaga ${ }^{1}$, J.P. Werne ${ }^{2}$ AND J.S. Sinninghe Damsté ${ }^{1,3}$ \\ ${ }^{1}$ Faculty of Geosciences, Utrecht University, The Netherlands; j.weijers@geo.uu.nl \\ ${ }^{2}$ Large Lakes Observatory and Department of Chemistry and Biochemistry, University of Minnesota Duluth, USA; ${ }^{3}$ Department of Marine Or- \\ ganic Biogeochemistry, Royal Netherlands Institute for Sea Research,'t Horntje (Texel), The Netherlands
}

\section{New organic geochemical technique has potential for reconstructing absolute lake surface and lake catchment temperatures in paleolimnological studies}

Lake sediments are an essential source of data on past climate change on the continents. Paleolimnological techniques designed to reconstruct continental temperature changes have primarily focused on carbonate sources and oxygen isotopes in biogenic silica (e.g., von Grafenstein et al., 1994; Rietti-Shanti et al., 1998). Transfer functions aimed at absolute temperature reconstructions from biological records are promising for pollen and chironomids (e.g., Walker et al., 1991; Lotter et al., 1997). Obviously, not all lake records contain carbonates, chironomids or pollen. Clearly, it is desirable to have different tools at hand for temperature reconstructions as the best reconstructions are to be obtained by means of multi-proxy approaches. An opportunity to expand this proxy "toolbox" comes from microbial cell membrane lipids, which might be used to reconstruct lake surface water temperatures and catchment air temperatures.

\section{Lake surface paleothermometer}

Because of their wide application in marine environments, considerable interest has developed in recent years for the application of isoprenoid Glycerol Dialkyl Glycerol Tetraether (GDGT) membrane lipids as temperature indicators of lakes. In the marine environment, these lipids are synthesized by pelagic non-thermophilic Crenarchaeota and the degree of inter- nal cyclization of GDGTs, expressed in the TEX $_{86}$ (TetraEther indeX of molecules containing 86 carbon atoms) shows a strong relation with sea surface temperature (Schouten et al., 2002; Kim et al., 2008). This proxy has since found many applications in marine sediment records (e.g., Sluijs et al., 2006). Further, preliminary analyses of surface sediments from four globally distributed large lakes by Powers et al. (2004) demonstrated the presence of crenarchaeotal GDGTs, and thus showed potential for application of TEX $_{86}$ in lacustrine systems. The initial calibration curve of $\mathrm{TEX}_{86}$ in lakes, based on comparison of the GDGT composition of lake surface sediments with published mean annual 


\section{Full Reference List:}

Brooks, S.J., 2006: Fossil midges (Diptera: Chironomidae) as palaeoclimatic indicators for the Eurasian region, Quaternary Science Reviews, 25: 1894-1910.

Cauchie, H.-M., 2002: Chitin production by arthropods in the hydrosphere, Hydrobiologia, 470: 6396.

Grey, J., 2006: The use of stable isotope analyses in freshwater ecology: Current awareness, Polish Journal of Ecology, 54: 563-584.

Huang, Y., Shuman, B., Wang, Y. and Webb III, T., 2004: Hydrogen isotope ratios of individual lipids in lake sediments as novel tracers of climatic and environmental change: A surface sediment test, Journal of Paleolimnology, 31: 363-375.

Jones, R.I. and Grey, J., 2004: Stable isotope analysis of chironomid larvae from some Finnish forest lakes indicates dietary contribution from biogenic methane, Boreal Environment Research, 9: 17-23.

Jones, R.I., Carter, C.E., Kelly, A., Ward, S., Kelly, D.J. and Grey, J., 2008: Widespread contribution of methane-cycle bacteria to the diets of lake profundal chironomid larvae, Ecology, 89: 857-864.

Kankaala, P., Taipale, S., Grey, J., Sonninen, E., Arvola, L. and Jones, R.I., 2006: Experimental $\delta^{13} \mathrm{C}$ evidence for a contribution of methane to pelagic food webs in lakes, Limnology and Oceanography, 51: 2821-2827.

Lotter, A.F., Eicher, U., Birks, H.J.B. and Siegenthaler, U., 1992: Late Glacial climatic oscillations as recorded in Swiss lake sediments, Journal of Quaternary Science, 7: 187-204.

Martinez del Rio, C., Wolf, N., Carleton, S.A. and Gannes, L.Z., 2009: Isotopic ecology ten years after a call for more laboratory experiments, Biological Reviews, 84: 91-111.

Meyers, P.A. and Lallier-Vergès, E., 1999: Lacustrine sedimentary organic matter records of Late Quaternary paleoclimates, Journal of Paleolimnology, 21: 345-372.

Miller, R.F., 1991: Chitin paleoecology, Biochemical Systematics and Ecology, 19: 401-411.

Nation, J.L., 2002: Insect physiology and biochemistry, CRC Press, Boca Raton.

Raabe, D., Sachs, C. and Romano, P., 2005: The crustacean exoskeleton as an example of a structurally and mechanically graded biological nanocomposite material, Acta Materialia, 53: 4281-4292.

Schimmelmann, A., accepted: Carbon, nitrogen and oxygen stable isotope ratios in chitin. In: Gupta, S.N. (Ed.), Chitin: formation and diagenesis, Springer.

Schimmelmann, A., DeNiro, M.J., Poulicek, M., Voss-Foucart, M., Goffinet, G. and Jeuniaux, C., 1986: Stable isotopic composition of chitin from arthropods recovered in archaeological contexts as palaeoenvironmental indicators, Journal of Archaeological Science, 13: 553-566.

Stankiewicz, B.A., Briggs, D.E.G., Evershed, R.P. and Duncan, I.J., 1997a: Chemical preservation of insect cuticle from the Pleistocene asphalt deposit of California, USA, Geochimica et Cosmochimica Acta, 61: 2247-2252.

Stankiewicz, B.A., Briggs, D.E.G., Evershed, R.P., Flannery, M.B. and Wuttke, M., 1997b: Preservation of chitin in 25-million-year-old fossils, Science, 276: 1541-1543.

van Hardenbroek, M., Heiri, O., Grey, J., Bodelier, P.L.E., Verbruggen, F. and Lotter, A.F., 2009a: Fossil chironomid $\delta^{13} \mathrm{C}$ as a proxy for past methanogenic contribution to benthic food webs in lakes? Journal of Paleolimnology, DOI 10.1007/s10933-009-9328-5.

van Hardenbroek, M., Heiri, O. and Lotter, A.F., 2009b: Efficiency of different mesh sizes for isolating fossil chironomids for stable isotope and radiocarbon analyses, Journal of Paleolimnology, DOI 10.1007/s10933-009-9327-6.

von Grafenstein, U., Erlenkeuser, H., Brauer, A., Jouzel, J. and Johnsen, S., 1999: A mid-European decadal isotope climate record from 15,500 to 5000 years BP, Science, 284: 1654-1657.

Wang, Y., Francis, D.R., O'Brien, D.M. and Wooller, M.J., 2008: A protocol for preparing subfossil chironomid head capsules (Diptera: Chironomidae) for stable isotope analysis in paleoclimate reconstruction and considerations of contamination sources, Journal of Paleolimnology, 40: 771-781.

Wang, Y.V., O'Brien, D.M., Jenson, J., Francis, D. and Wooller, M.J., 2009: The influence of diet and water on the stable oxygen and hydrogen isotope composition of Chironomidae (Diptera) with paleoecological implications, Oecologia, DOI 10.1007/s00442-009-1303-3.

Wolfe, B.B., Falcone, M.D., Clogg-Wright, K.P., Mongeon, C.L., Yi, Y., Brock, B.E., St. Amour, N.A., Mark, W.A. and Edwards, T.W.D., 2007: Progress in isotope paleohydrology using lake sediment cellulose, Journal of Paleolimnology, 37: 221-231. 
Wooller, M.J., Francis, D., Fogel, M.L., Miller, U., Walker, I.R. and Wolfe, A.P., 2004: Quantitative paleotemperature estimates from $\delta^{18} \mathrm{O}$ of chironomid head capsules preserved in arctic lake sediments, Journal of Paleolimnology, 31: 267-274.

Wooller, M., Wang, Y. and Axford, Y., 2008: A multiple stable isotope record of Late Quaternary limnological changes and chironomid paleoecology from northeastern Iceland, Journal of Paleolimnology, 40: 63-77. 